\title{
Therapy Aimed to Suppress the Production of the Immunosuppressive Protein Progesterone Induced Blocking Factor (PIBF) May Provide Palliation and/or Increased Longevity for Patients With a Variety of Different Advanced Cancers - A Review
}

\author{
JEROME H. CHECK ${ }^{1,2}$ and DIANE CHECK ${ }^{2}$ \\ ${ }^{1}$ Department of Obstetrics and Gynecology, Division of Reproductive Endocrinology and Infertility, \\ Cooper Medical School of Rowan University, Camden, NJ, U.S.A.; \\ ${ }^{2}$ Cooper Institute for Reproductive Hormonal Disorders, P.C., Mt. Laurel, NJ, U.S.A.
}

\begin{abstract}
Progesterone induced blocking factor (PIBF) is a unique protein that is not present in normal cells, but is found predominantly in rapidly growing cells of the fetal placental unit or cancer cells. There is a larger "parent" form that is a nuclear protein involved in cell to cell regulation, allowing tumor cells to proliferate and invade tissues. The parent compound is cleaved into smaller intracytoplasmic isoforms that can suppress cellular immune response, especially, but not limited to natural killer cells. The progesterone receptor antagonist mifepristone can suppress messenger RNA for PIBF, but can also suppress the intracytoplasmic protein. Treating cancer cell lines, intact animals with a variety of spontaneous cancers, and people with various cancers with mifepristone, has been found to inhibit cancer growth, and provide both palliation of symptoms and longevity possibly by suppressing this unique immunomodulatory protein.
\end{abstract}

\section{The Progesterone Induced Blocking Factor (PIBF)}

The progesterone induced blocking factor (PIBF) is an immunomodulatory protein that can suppress or block

Correspondence to: Jerome H. Check, MD, Ph.D., Cooper Medical School of Rowan University, 7447 Old York Road, Melrose Park, PA 19027, U.S.A. Tel: +1 2156354156, Fax: +1 2156352304, e-mail: laurie@ccivf.com

Key Words: Progesterone induced blocking factor, immunosuppression, progesterone receptor modulators, natural killer cells, rapidly growing cancer cells, immunology of pregnancy, review. various aspects of the immune system, especially, but not limited to, natural killer (NK) cells $(1,2)$. Because exposure to progesterone can cause a precipitous rise in expression of this immunomodulatory protein both in gamma/delta lymphocytes and in the serum, it has been termed the progesterone induced blocking factor $(3,4)$. The blocking effect on cellular immunity, especially NK cell cytolytic activity, may be related, at least in part, to a shift from thymic helper (TH)-1 to TH2 cytokine dominance $(5,6)$. At least one-way PIBF blocks NK cell cytolytic activity is by inhibiting degranulation of perforin granules, which is one method used by NK cells to kill other cells (7).

There are at least two forms of PIBF. The "parent' form has a molecular mass of $90 \mathrm{kDa}$ and is localized in the centrosome (8). Various splice variants of this nuclear protein lead to smaller intracytoplasmic molecules that have immunosuppressive activity. For example, one of the most common splice variants has a molecular mass of $35 \mathrm{kDa}$, results from the exon 1-5 +17-18 transcript and contains the N-terminal 223 and C-terminal 75 amino acids (8). The actual full-length protein consists of 757 amino acids and the 48-kDa $\mathrm{N}$-terminal part is biologically active (9). This 757 -amino acid protein is unique in that it has no significant amino acid sequence homology with any known protein (9). The PIBF gene has been identified on chromosome 13 in the vicinity of breast cancer $1(B R C A 1)$ or $B R C A 2$ or $p 53(8,10,11)$.

PIBF protein is secreted from two main sources. The gamma/delta T-cell seems to be the main source of PIBF found in the serum (6). The serum levels of PBF will rise precipitously in the presence of progesterone $(\mathrm{P})$, even in males $(12,13)$.

The PIBF protein is also expressed in the cytoplasm of rapidly growing cells $(8,14)$. For the fetal-placental unit, these 
include mesenchymal cells, embryonic cells and trophoblast cells (12). Various isoforms of the PIBF protein have been found in cancer cells. The 34-36 kDa splice variant, similar to the PIBF protein circulating in the blood stream found in high levels in people exposed to $\mathrm{P}$, is the most common form ( 8 , 14). However, splice variants of the parent $90-\mathrm{kDa}$ nuclear parent form have been found in the cytoplasm of some cancer cells measuring 57 and $67 \mathrm{kDa}(15,16)$.

\section{The Effect of Progesterone, Progestins, and Progesterone Receptor Modulators on Serum and Intracytoplasmic PIBF Levels}

Whereas exposure to progesterone causes a marked increase in serum PIBF blood levels, synthetic progestins, e.g., medroxyprogesterone acetate, 19-nor testosterone derivatives (as seen in oral contraceptives), dydrogesterone, or even the naturally occurring 17-hydroxyprogesterone fail to raise serum PIBF levels $(12,13,17)$. Exposure to progesterone also markedly increases intracytoplasmic PIBF levels and very significantly increases PIBF mRNA levels (14).

In contrast, the progesterone receptor modulators mifepristone and ulipristal do not decrease serum levels of PIBF, showing that progesterone receptors on gamma/delta T-cells are not affected by these selective progesterone receptor modulators $(18,19)$. However, mifepristone has been demonstrated to suppress intracytoplasmic 35-kDa PIBF protein in a large variety of leukemia cell lines (14). Mifepristone has also been demonstrated to suppress the intracytoplasmic $57 \mathrm{kDa}$ PIBF isoform found in human glioblastoma multiforme cells (20).

The nuclear form of PIBF may be involved in cell growth. The addition of PIBF to a glioblastoma multiforme cell line led to an increase in the number of U87 cells on days 4 and 5 of the treatment, suggesting that PIBF promotes migration and invasion of glioblastoma cancer cells (20). Lachman et $a l$., found PIBF to be highly expressed in cell lines from adenocarcinomas of the cervix, breast (T47D, Sloan Kettering 3 and MCF) and ovary (OVCAR-3) (8). Mifepristone has been found to inhibit the growth of cell lines or murine transplantation from endometrial cancer, breast cancer, prostate cancer, ovarian cancer, and gastric cancer (21-26). Some other cell line studies have shown that mifepristone treatment in combination with cisplatin inhibited growth of ovarian cell lines better than cisplatin alone (27-31).

\section{A Simplified Hypothetical Model of how the Fetal Placental Unit Utilizes PIBF to Evade Immune Rejection of the Fetal Semi-Allograft from Natural Killer (NK) Cells}

Many immunosuppressive molecules are needed to inhibit immune rejection of the fetus. Two editorials have provided an insight as to the need to especially suppress NK cells and how PIBF may be the main immunosuppressive protein to accomplish this feat $(32,33)$.

A simplified model to explain the relationship of NK cells, growth of the fetal placental unit and escape from immune surveillance from NK cells is as follows: Progesterone inhibits the biogenic amine dopamine. One of the functions of dopamine is to inhibit cellular permeability. By suppressing dopamine, irritating elements infuse into the endometrium causing an inflammatory response (32). This inflammatory response leads to an accumulation of NK cells, which represent $70 \%$ of the endometrial white cell population $(32,34-37)$. These NK cells function to chop out the thick walls of some of the uterine arteries to be replaced by a single layer of trophoblast cells shed from the extravillous trophoblast $(32,36)$. These new vessels, known as spiral arterioles, are sufficiently thin-walled to allow nutrient exchange from mother to fetus $(32,36)$.

Trophoblast invasion is directed by uterine NK cells also. They express the chemokines IL- 8 and IP-10, which bind the receptors CXCR1 and CXCR3 on the extra-villous trophoblast cells (37). This directs the conceptus to attach to the hole made in the mucin 1 layer coating the endometrium that has precluded attachment of the conceptus for 6 days to allow uterine remodeling (32).

The problem now facing the conceptus, that is invading the re-modeled implantation site, is that these same NK cells, required for these important events in a successful pregnancy, could now attack the fetal semi-allograft and abort the pregnancy. However, this hypothetical model contends that while progesterone was responsible for attracting the NK cells, progesterone has simultaneously been busy establishing a method to negate the ability of NK cells to kill by inhibiting perforin release and possibly granzymes, by increasing the intracytoplasmic concentration of PIBF in the rapidly growing fetal-placental cells (32-34).

Naturally, models for a given physiological state can be modified as new research is performed. Nevertheless, a good present-day model is important in understanding pathological states related to abnormal physiological conditions. Understanding these various models can lead to treatments that can obviate the pathological state.

For example, based on this model, infertility or miscarriage can be related to excessive cellular permeability, leading to excessive NK cells and/or insufficient PIBF to neutralize them. Indeed, based on this model, supplementation with progesterone in the luteal phase and during the first trimester should correct some infertility states, or prevent miscarriage, and, indeed, this supplementation has corrected these pathological states (38-40). Similarly, taking medication that can release more dopamine from sympathetic nerve fibers can diminish excessive permeability, not only leading to amelioration of a large number of treatment refractory pathological states, but can decrease the risk of miscarriage (41-43). 
This model would also explain why taking the progesterone receptor modulator mifepristone, for just one day, could lead to subsequent fetal demise in a large number of cases, leading to the use of the $200 \mathrm{mg}$ oral dosage as an abortifacient. Since death is not immediate, the drug would not seem to act as an immediate poison, e.g., stopping heart function, but by causing a cellular immune attack, possibly, predominantly by NK cells, by suppressing intracytoplasmic PIBF in rapidly growing cells of the fetal-placental unit.

\section{Potential Cancer Immunotherapy Based on Similarities of the Mechanisms Shared by the Fetal Placental Unit and Cancer: Animal Research}

The possible role of PIBF in enabling both the conceptus and malignant tumor to escape immune surveillance was hypothesized in 2001 (44). With further research, the model was modified shifting the emphasis from PIBF made by circulating gamma/delta T-cells to the cancer cells themselves (45).

Based on the knowledge that the progesterone receptor modulator mifepristone, which is already on the market, can suppress the immunosuppressive function of intracytoplasmic PIBF, and terminate a pregnancy, its effect on cancer progression was examined.

However, not all cancer cell lines expressing PIBF are associated with malignant tumors positive for the classic nuclear progesterone receptor. Also, cell line studies do not take into account the fact that a certain therapeutic agent can be effective through chemical interactions in the intact animal. In choosing animal models, a more credible animal model would be one that evaluates spontaneous cancer, and especially spontaneous cancers that are not associated with the classic nuclear progesterone receptor (46).

Controlled studies gavaging mice with spontaneous cancers, including leukemia, testicular, prostate, and lung cancer with oral mifepristone, calculated on a weight basis to be the equivalent of $200 \mathrm{mg}$ per day for humans, demonstrated significant palliative benefits and increased longevity in these animal models (47-49). For example, for $\mathrm{A} / \mathrm{J}$ mice with spontaneous lung cancer, $67.4 \%$ treated with mifepristone survived 1 year vs. $27 \%$ of the controls (49). There were $66.7 \%$ of mice treated with mifepristone with no sick days (body conditioning scores <4) vs. zero \% for controls (49).

\section{Anecdotal Human Studies Using Mifepristone to Treat Advanced Cancers}

Though not approved for cancer therapy, as mentioned, mifepristone is already a manufactured drug used in the $200 \mathrm{mg}$ dosage for inducing therapeutic abortions, and in the $300 \mathrm{mg}$ dosage for hyperglycemia associated with Cushing's syndrome. Although most governments allow off-label prescription of most drugs, in most countries due to consideration of abortion, the $200 \mathrm{mg}$ of mifepristone is used by licensed abortionists. In order to use the $200 \mathrm{mg}$ dosage in the United States, one must obtain a compassion use investigational new drug (IND) approval on a case by case basis.

The following advanced treatment refractory cancers have shown some palliative benefits from oral mifepristone 200 mg per day: colon cancer, glioblastoma multiforme, thymic cell epithelial cell cancer, transitional cell carcinoma of the renal pelvic, pancreatic cancer, malignant fibrous histocytoma, leiomyosarcoma, probable small cell lung cancer, and renal cell carcinoma (50-53).

Actually, all three patients with advanced metastatic colon cancer showed significant palliative benefits taking single agent mifepristone therapy at a dose of $200 \mathrm{mg} /$ day $(50,52)$. One woman, aged 61 years old, had invasive moderately differentiated adenocarcinoma of the transverse colon with extensive metastases to the liver, peritoneum, ovary and uterus. Her oncologist suggested a chemotherapy regimen and stated that it would increase her chance of survival at 6 months to $15 \%$, but otherwise death would occur within a month or two. Instead, she elected to try single agent oral mifepristone therapy at a dose of $200 \mathrm{mg}$ daily, which was obtained with a compassionate use IND. She was an ECOG2 at this time. After 5 weeks of mifepristone her energy levels returned to normal, and had total relief of pain. She was now ECOG-0. She was sill perfect at 18 months of treatment, when, because of expense (\$500/month), she asked if she could stop the medication. With little experience, it was agreed to stop it, and simply restart the mifepristone if the cancer started to advance again. At that time there still was evidence of metastatic disease, but no lesions had grown, and many were smaller. Her carcinoembryonic analysis was only $1.3 \mathrm{ng} / \mathrm{ml}$. Three months off the drug she developed ascites, though she was still painfree, and had good energy. The mifepristone was started again, but it did not seem as effective on the second round, and she died 30 months from starting the mifepristone (50).

Another example of a great response to mifepristone 200 mg daily was an 80-year old woman admitted to the intensive care unit with a serum $\mathrm{PO}_{2}$ of $72 \mathrm{mmol} / \mathrm{l}$. The radiologic and clinical diagnosis was probable advanced lung cancer with the syndrome of inappropriate antidiuretic hormone (SIADH) related to ectopic production of arginine vasopressin (53). The oncologist thought that based on the rapidity of the presentation, and with SIADH, that the most likely diagnosis was advanced small-cell lung cancer. The patient refused surgical confirmation, and refused standard chemotherapy, but agreed to take $200 \mathrm{mg}$ oral mifepristone on a compassionate basis. Within one month her $\mathrm{PO}_{2}$ returned to $99-100 \mathrm{mmHg}$ and her serum sodium returned to 
$145 \mathrm{mmol} / \mathrm{l}$ from $118 \mathrm{mmol} / \mathrm{l}$. Ten weeks after initiation of treatment all her lung lesions were gone by CT scan. Her CT-scan showed no tumors 5 years after single agent mifepristone therapy. She died $51 / 2$ years after initiation of mifepristone therapy of a sudden myocardial infarction (53). Very good responses have also been seen with thymic cell epithelial cancer and leiomyosarcoma (52).

These cases provided new insight into treatment with this drug. For one thing, as evidenced by the colon cancer and the thymic epithelial cell cancer cases, once one stops the drug, there can be very rapid lethal progression. Thus, the drug seems to stop the cancer from growing, and even showing regression or remission, but the cancer is not eradicated, and the cancer is geared to rapidly progress if the "block" is removed when the progesterone receptor modulator is stopped. Moreover, the leiomyosarcoma case shows that even if the drug is starting to show some progression, it is probably not wise to stop the drug and try another treatment modality, unless this new treatment is very likely to work (52). Disease progression is likely to be so slowed that significant longevity and palliation will still occur as long as the drug is continued even if there appears to be progressive disease.

It should be noted that the 58 -year old male with bilateral renal cell carcinoma who refused to remove his left kidney to prevent dialysis, with 3 lesions present, is still alive and doing well 15 years later while being treated with single agent mifepristone (remaining left kidney and remainder of right kidney only removed 11 years later when his diabetes caused complete kidney failure. He has received a kidney transplant) (53).

\section{A phase II study of treatment with oral mifepristone as salvage therapy in patients with advanced or metastatic non-small cell lung cancer who have failed two or more previous chemotherapy or immunotherapy regimens}

The benefits of mifepristone therapy in controlled murine cancer models, and some of the dramatic aforementioned responses in anecdotal cases, have convinced the present authors of the efficacy of mifepristone in increasing longevity and/or providing palliation for patients with advanced cancers. However, to convince a large group of oncologists, a larger clinical study is needed, to not only confirm the efficacy of this treatment in some cases, but to determine what percentage of advanced cancer cases will be provided significant palliative benefit from mifepristone therapy.

This study of stage IIIB or IV non-small cell lung cancer was approved for 40 patients and 2 principal investigators. Unable to find willing oncologists to be principal investigators in this investigator-initiated study, the lead author became the sole principal investigator. Based on past experience, the primary end-points were quality of life and longevity, with disease progression as only a secondary endpoint.

The first patient presented at age 68 with stage IV lung cancer with brain metastasis who had failed three platinumbased chemotherapy regimens (46). Since he had no tumor markers for targeted therapy, he was told there were no other treatment options. He was started on $300 \mathrm{mg}$ oral mifepristone daily and has now completed 43 twenty-eight-day treatment cycles. He is still ECOG zero and answers all 43 quality of life questions with "not at all". Most lesions have regressed or remained stable. One lesion is slowly growing but is showing necrosis. There have been no more brain lesions.

The second patient in the study was a 66-year-old woman. This patient was positive for the epidermal growth receptor (EGFR) mutation and the programmed cell death protein ligand-1 marker (PD-L1) (54). Her non-small cell lung cancer progressed despite platinum-based chemotherapy, erlotinib, and nivolumab. She showed arrest of cancer progression, and significant palliative benefits after 18 months of mifepristone therapy. Unfortunately, she died from pneumonia complicating her end stage chronic obstructive lung disease (54). Her lung cancer had not progressed (54).

\section{Status of Mifepristone Therapy for Advanced Cancer as of $\mathbf{2 0 1 9}$}

Unfortunately, to date, after almost four years, these are the only two patients with ECOG 3 status or less recruited for this investigator-initiated study. This is partly related to competition for advanced cancer patients to be used in drug trials by various pharmaceutical companies.

Mifepristone, especially in the $200 \mathrm{mg}$ dosage, is generally well tolerated when used long-term, as seen in studies using it for unresectable meningiomas (55). Hopefully, the 2019 publication showing that mifepristone can thwart PD-L1 positive cancer, even when progression occurred despite treatment with check-point inhibitors, will generate interest to offer this treatment, not just to patients with advanced non-small cell lung cancer, but also to patients suffering from other cancers. Furthermore, interest will be influenced by the aforementioned anecdotal cases, knowledge of which cancer cell lines express the PIBF protein, or knowledge of which spontaneous murine cancers respond to mifepristone. As a generic drug, mifepristone can be obtained in some countries for as little as 50 cents a pill.

In the United States, the FDA has made the methodology to obtain compassionate use much simpler. Hopefully, other governments will merely allow those physicians who are interested in treating their cancer patients with mifepristone to merely prescribe the drug off-label without obtaining an 
IND. Hopefully, if physicians do prescribe mifepristone, they will keep careful records and report their experiences whether positive or negative. Hopefully positive reports from more than one treatment center will generate interest in performing larger clinical trials, which will examine the efficacy of progesterone receptor modulators for treating cancer.

Also, the hope of writing this review is that it will generate interest in scientists to evaluate in more detail this unique PIBF protein. A computer search found a paucity of research concerning this immunomodulatory protein. There are still so many questions to be answered which could lead to other, possibly superior, cancer therapies.

One question is how cancer cells activate the progesterone receptor, which is probably a membrane associated progesterone receptor, rather than a nuclear receptor (56). Is it possible that some cancers produce human chorionic gonadotropin, which, in turn, produces progesterone locally, which stimulates the membrane associated $\mathrm{P}$ receptors, leading to an increase in both nuclear and intracytoplasmic PIBF $(38,46,57)$ ? Theoretically, this level of $\mathrm{P}$ is insufficient to raise the serum progesterone levels, and thus serum PIBF is not increased in the patients with cancer (58-60).

Another important question is at which level does PIBF operate? Could this immunosuppressive protein be critical for cancer stem cell proliferation? This seems plausible since mifepristone, which suppresses intracytoplasmic PIBF, has been shown to cause regression of cancer, or at least significant palliative relief, even when standard therapies directed against rapidly growing cells have ceased to be effective (a time when most theorize that the majority of the cancer cells may be stem cells).

Future studies should be directed at determining which tumors on biopsy express the PIBF protein. Also, will mifepristone only inhibit cancer growth of cells expressing PIBF, or could PIBF expression not be present on the biopsied early stage cancer, but be present when the tumor reaches the rapidly growing metastatic stage? In 2018, Madendag et al. found high immune expression of PIBF in epithelial ovarian cancers (61). They concluded that "further research is needed to understand the clinical importance of this finding, to learn outcomes of high levels of PIBF, and to investigate its underlying mechanisms" (61).

Future studies aimed at eliciting more precisely the effect of intracytoplasmic PIBF on the immune system could help to develop other novel therapies aimed at blocking these pathways, or methods of enhancing the efficacy of progesterone receptor modulators. These intracytoplasmic isoforms of the nuclear PIBF protein may be ligands of various immune pathways, e.g., acting as ligands of the PIBF receptor/interleukin-4 receptor and heterocomplex, e.g., IL$4 \mathrm{R} / \mathrm{Janus}$ kinase/STAT 6 proliferating pathway which is associated with the differentiation of $\mathrm{TH} 2$ cells to produce a specific set of cytokines (62).
As previously mentioned, mifepristone can suppress proliferation of cancer cell lines (23-31). This suppression is not likely through the immune system, since this would require an intact animal. Most likely the mechanism involves suppression of a molecule that inhibits proliferation mediated by the nuclear $90-\mathrm{kDa}$ parental form of the PIBF protein $(8$, 46). It is likely that the antagonism of mifepristone on cancer cell proliferation would more likely involve nuclear, rather than intracytoplasmic PIBF.

There is evidence that PIBF (most likely nuclear PIBF) may help enable malignant tumors to invade tissues by stimulating proteolytic enzymes, e.g., matrix metalloproteinases (63). Another possible role of mifepristone is to inhibit cytotoxic T-cells from adhering to vascular endothelium (64). In the aforementioned study by Lachman et al., they found that PIBF may not be an integral part of the centrosome but rather a microtubule-associated protein (8). This could suggest that other therapies, in addition to progesterone receptor modulators, could be used to disrupt PIBF function, e.g., microtubule disrupting agents, e.g., nocodazole (8).

Another important question is whether early use of mifepristone, possibly combined with other chemo or immunotherapeutic agents may prove to significantly enhance longevity and quality of life compared to the use of either treatment alone, as seen in certain cell line studies (26-31).

Hopefully, in 2019, we will see a significant increase in scientists and physicians researching the importance of the PIBF protein and the importance of progesterone receptor modulators in the treatment of cancer. One caveat is that, based on experiences to date, clinical studies should make their primary endpoint longevity and quality of life, as opposed to progressive disease, similar to the aforementioned investigator-initiated evaluation of single-agent mifepristone therapy for advanced non-small cell lung cancer.

\section{Conflicts of Interest}

The Authors have no conflicts of interest to declare regarding this study.

\section{Authors' Contributions}

The majority of the manuscript was written by the lead author Jerome H. Check. The section entitled "A phase II study of treatment with oral mifepristone as salvage therapy in patients with advanced or metastatic non-small cell lung cancer who have failed two or more previous chemotherapy or immunotherapy regimens" was written by the co-author, Diane Check.

\section{References}

1 Pence H, Petty WM and Rocklin RE: Suppression of maternal responsiveness to paternal antigens by maternal plasma. J Immunol 114: 525-528, 1975. PMID: 123259. 
2 Szekeres-Bartho J, Kilar F, Falkay G, Csernus V, Török A and Pacsa AS: The mechanism of the inhibitory effect of progesterone on lymphocyte cytotoxicity: I. Progesterone-treated lymphocytes release a substance inhibiting cytotoxicity and prostaglandin synthesis. Am J Reprod Microbiol 9: 15-18, 1985. PMID: 3863495

3 Szekeres-Bartho J, Annan B, Debre P, Andreu G, Denver L and Chaouat G: Immunoregulatory effects of a suppressor factor from healthy pregnant women's lymphocytes after progesterone induction. Cell Immunol 122: 281-294, 1989. PMID: 2527616.

4 Check JH, Szekeres Bartho J and O'Shaughnessy A: Progesterone induced blocking factor seen in pregnancy lymphocytes soon after implantation. Am J Reprod Immunol 35: 277-280, 1996. PMID: 8962661.

5 Szekeres-Bartho J, Falkay G, Torok A and Pacsa AS: The mechanism of the inhibitory effect of progesterone on lymphocyte cytotoxicity: II. Relationship between cytotoxicity and the cyclooxygenase pathway of arachidonic acid metabolism. Am J Reprod Immunol Microbiol 9: 19-22, 1985. PMID: 3931486.

6 Szekeres-Bartho J, Barakonyi A, Polgar B, Par G, Faust Z, Palkovics T and Szereday L: The role of gamma/delta T cells in progesterone-mediated immunomodulation during pregnancy: a review. Am J Reprod Immunol 42: 44-48, 1999. PMID: 10429766

7 Faust Z, Laskarin G, Rukavina D and Szekeres-Bartho J: Progesterone induced blocking factor inhibits degranulation of NK cells. Am J Reprod Immunol 42: 71-75, 1999. PMID: 10476687.

8 Lachmann M, Gelbmann D, Kalman E, Polgar B, Buschle M, von Gabain A, Szekeres-Bartho J and Nagy E: PIBF (progesterone induced blocking factor) is overexpressed in highly proliferating cells and associated with the centrosome. Int J Cancer 112: 51-60, 2004. PMID: 15305375. DOI: 10.1002/ ijc. 20326

9 Polgar B, Kispal GY, Lachmann M, Paar C, Nagy E, Csere P, Miko E, Szereday L, Varga P, and Szekeres-Bartho J: Molecular cloning and immunological characterization of a novel cDNA coding for PIBF. J Immunol 171: 5956-5963, 2003. PMID: 14634107. DOI: $10.4049 /$ jimmunol.171.11.5956

$10 \mathrm{Xu}$ X, Weaver Z, Linke SP, Li C, Gotay J, Wang XW, Harris CC, Ried $\mathrm{T}$ and Deng CX: Centrosome amplification and a defective G2-M cell cycle checkpoint induce genetic instability in BRCA1 exon 11 isoform-deficient cells. Mol Cell 3: 389-395, 1999. PMID: 10198641.

11 Rozenblum E, Vahteristo P, Sandberg T, Bergthorsson JT, Syrjakoski K, Weaver D, Haraldsson K, Johannsdottir HK, Vehmanen P, Nigam S, Golberger N, Robbins C, Pak E, Dutra A, Gillander E, Stephan DA, Bailey-Wilson J, Juo SH, Kainu T, Arason A, Barkardottir RB, Nevanlinna H, Borg A and Kallioniemi OP: A genomic map of a 6-Mb region at 13q21-q22 implicated in cancer development: identification and characterization of candidate genes. Hum Genet 110: 111-121, 2002. PMID: 11935316. DOI: 10.1007/s00439-001-0646-6

12 Cohen RA, Check JH and Dougherty MP: Evidence that exposure to progesterone alone is a sufficient stimulus to cause a precipitous rise in the immunomodulatory protein the progesterone induced blocking factor (PIBF). J Assist Reprod Genet 33: 221-229, 2016. PMID: 26634256. DOI: 10.1007/ s10815-015-0619-7
13 Check JH, Cohen R, Jaffe A, Tran J and Sarumi M: An allogeneic stimulus is not a prerequisite for the expression of the immunomodulatory protein the progesterone induced blocking factor (PIBF). In: 14th International Symposium for Immunology of Reproduction, Boston, Massachusetts, May 28 - June 1, 2013. Am J Reprod Immunol 69(S2): 51, pp. 14, 2013.

14 Srivastava MD, Thomas A, Srivastava BI and Check JH: Expression and modulation of progesterone induced blocking factor (PIBF) and innate immune factors in human leukemia cell lines by progesterone and mifepristone. Leuk Lymphoma 48: 1610-1617, 2007. PMID: 17701593. DOI: $10.1080 / 10428$ 190701471999

15 Kyurkchiev D, Naydenov E, Tumangelova-Yuzeir K, IvanovaTodorova E, Belemezova K, Bochev I, Minkin K, Mourdjeva M, Velikova T, Nachev S and Kyurkchiev S: Cells isolated from human glioblastoma multiforme express progesterone-induced blocking factor (PIBF). Cell Mol Neurobiol 34(4): 479-489, 2014. PMID: 24474429. DOI: 10.1007/s10571-014-0031-3

16 Gonzalez-Arenas A, Valadez-Cosmes P, Kimenez-Arellano C, Lopez-Sanchez M and Camacho-Arroyo I: Progesterone-induced blocking factor is hormonally regulated in human astrocytoma cells, and increases their growth through the IL-4R/JAK1/STAT6 pathway. J Steroid Biochem Mol Biol 144 Pt B: 463-470, 2014. PMID: 25218441. DOI: 10.1016/j.jsbmb.2014.09.007

17 Check JH, Dougherty MP, DiAntonio G and DiAntonio A: The effect of dydrogesterone $v s$. oral micronized progesterone $(\mathrm{P})$ on serum levels of the progesterone induced blocking factor (PIBF). $I n$ : Proceedings of the 18th World Congress of In Vitro Fertilization, September 27-30, Copenhagen, Denmark, abstract nr. 51, 2015.

18 Check JH, DiAntonio G, DiAntonio A and Duroseau M: The progesterone receptor antagonist mifepristone does not lower serum progesterone induced blocking factor (PIBF) in the presence of progesterone. Clin Exp Obst Gynecol 43: 189-191, 2016. PMID: 27132407.

19 Check JH, DiAntonio G, DiAntonio A and Dougherty MP: The effect of ingesting the selective progesterone receptor modulator ulipristal on serum levels of the immunomodulatory protein the progesterone induced blocking factor (PIBF). In: Proceedings of the 18th World Congress of In Vitro Fertilization, September 2730, Copenhagen, Denmark, abstract nr. 52, 2015.

20 Zamora-Sanchez CJ, Hansberg-Pastor V, Salido-Guadarrama I, Rodriguez-Dorantes $\mathrm{M}$ and Camacho-Arroyo: Allopregnanolone promotes proliferation and differential gene expression in human glioblastoma cells. Steroids 119: 36-42, 2017. PMID: 28119080. DOI: $10.1016 / j$.steroids.2017.01.004

21 Poole AJ, Li Y, Kim Y, Lin SC, Lee WH and Lee EY: Prevention of Brcal-mediated mammary tumorigenesis in mice by a progesterone antagonist. Science 314: 1467-1470, 2006. PMID: 17138902. DOI: 10.1126/science.1130471

22 El Etreby MF, Liang Y, Johnson MH and Lewis RVV: Antitumor activity of mifepristone in the human $\mathrm{LNCaP}, \mathrm{LNCaP}-\mathrm{C} 4$, and LNCaP-C4-2 prostate cancer models in nude mice. Prostate 42: 99-106, 2000. PMID: 10617866.

23 Rose FV and Barnea ER: Response of human ovarian carcinoma cell lines to antiprogestin mifepristone. Oncogene 12: 999-1003, 1996. PMID: 8649817.

24 Goyeneche AA, Caron RW and Telleria CM: Mifepristone inhibits ovarian cancer cell growth in vitro and in vivo. Clin Cancer Res 13: 3370-3379, 2007. PMID: 17545545. DOI: 10.1158/1078-0432.CCR-07-0164 
25 Li DQ, Wang ZB, Bai J, Zhao J, Wang Y, Hu K and Du YH: Effects of mifepristone on proliferation of human gastric adenocarcinoma cell line SGC-7901 in vitro. World J Gastroenterol 10: 2628-2631, 2004. PMID: 15309708. DOI: 10.3748/wjg.v 10.i18.2628

26 Freeburg EM, Goyeneche AA, Seidel EE and Telleria CM: Resistance to cisplatin does not affect sensitivity of human ovarian cancer cell lines to mifepristone cytotoxicity. Cancer Cell Int 9: 4, 2009. PMID: 19222856. DOI: 10.1186/1475-2867-9-4

27 Gamarra-Luques CD, Goyeneche AA, Hapon MB and Telleria $\mathrm{CM}$ : Mifepristone prevents repopulation of ovarian cancer cells escaping cisplatin-paclitaxel therapy. BMC Cancer 12: 200, 2012. PMID: 22642877. DOI: 10.1186/1471-2407-12-200

28 Freeburg EM, Goyeneche AA and Telleria CM: Mifepristone abrogates repopulation of ovarian cancer cells in between courses of cisplatin treatment. Int J Oncol 34: 743-755, 2009. PMID: 19212679. DOI: 10.3892/ijo_00000200

29 Zhang L, Hapon MB, Goyeneche AA, Srinivasan R, GamarraLuques CD, Callegari EA, Drappeau DD, Terpstra EJ, Pan B, Knapp JR, Chien J, Wang X, Eyster KM and Telleria CM: Mifepristone increases mRNA translation rate, triggers the unfolded protein response, increases autophagic flux, and kills ovarian cancer cells in combination with proteasome or lysosome inhibitors. Mol Oncol 10: 1099-1117, 2016. PMID: 27233943. DOI: $10.1016 /$ j.molonc.2016.05.001

30 Gamarra-Luques CD, Hapon MB, Goyeneche AA and Telleria CM: Resistance to cisplatin and paclitaxel does not affect the sensitivity of human ovarian cancer cells to antiprogestininduced cytotoxicity. J Ovarian Res 7: 45, 2014. PMID: 24795781. DOI: $10.1186 / 1757-2215-7-45$

31 Goyeneche AA, Seidel EE and Telleria CM: Growth inhibition induced by antiprogestins RU-38486, ORG-31710, and CDB2914 in ovarian cancer cells involves inhibition of cyclin dependent kinase 2. Invest New Drugs 30: 967-980, 2012. PMID: 21424700. DOI: 10.1007/s10637-011-9655-z

32 Check JH, Aly J and Chang E: Improving the chance of successful implantation - part I - embryo attachment to the endometrium and adequate trophoblast invasion. Clin Exp Obst Gynecol 43: 787-791, 2016. PMID: 29944223.

33 Check JH and Aly J: Improving the chance of successful implantation - part 2 - Circumventing immune rejection and the fetal semi-allograft. Clin Exp Obst Gyn 45: 9-13, 2018. DOI: $10.12891 / \operatorname{ceog} 4381.2018$

34 Trundley A and Moffett A: Human uterine leukocytes and pregnancy. Tissue Antigens 63: 1-12, 2004. PMID: 14651517.

35 Bulmer JN, Williams PJ and Lash GE: Immune cells in the placental bed. Int J Dev Biol 54: 281-294, 2010. PMID: 19876837. DOI: $10.1387 / \mathrm{ijdb} .082763 \mathrm{jb}$

36 Erlebacher A: Immunology of the maternal-fetal interface. Annu Rev Immunol 31: 387-411, 2013. PMID: 23298207. DOI: 10.1146/annurev-immunol-032712-100003

37 Hanna J, Goldman-Wohl D, Hamani Y, Avraham I, Greenfield C, Natanson-Yaron S, Prus D, Cohen-Daniel L, Arnon TI, Manaster I, Gazit R, Yutkin V, Benharroch D, Porgador A, Keshet E, Yagel S and Mandelboim O: Decidual NK cells regulate key developmental processes at the human fetalmaternal interface. Nat Med 12: 1065-1074, 2006. PMID: 16892062. DOI: $10.1038 / \mathrm{nm} 1452$

38 Check JH and Cohen R: The role of progesterone and the progesterone receptor in human reproduction and cancer. Exp
Rev Endocrinol Metab 8: 469-484, 2013. PMID: 30754194. DOI: $10.1586 / 17446651.2013 .827380$

39 Check JH: Progesterone therapy versus follicle maturing drugs possible opposite effects on embryo implantation. Clin Exp Obst Gyn 29: 5-10, 2002. PMID: 12013095.

40 Check JH: Pros and cons of the use of progesterone to reduce miscarriage rates. Clin Exp Obst Gyn 45: 652-655, 2018. DOI: 10.12891/ceog4693.2018

41 Check JH: Sympathomimetic amines are a safe, highly effective therapy for several female chronic disorders that do not respond well to conventional therapy. Clin Exp Obst Gyn 42: 267-278, 2015. PMID: 26151991.

42 Check JH: Changing the name of a syndrome: sympathetic neural hyperalgesia edema syndrome becomes - the increased cellular permeability syndrome. Clin Exp Obst Gyn 44: 819-823, 2017. DOI: $10.12891 / \operatorname{ceog} 3883.2017$

43 Check JH, Chern R and Katsoff B: Prevention of first-trimester miscarriage with dextroamphetamine sulfate treatment in women with recurrent miscarriage following embryo transfer - case report. Clin Exp Obstet Gynecol 40: 471-472, 2013. PMID: 24597235.

44 Check JH, Nazari P, Goldberg J, Yuen W and Angotti D: A model for potential tumor immunotherapy based on knowledge of immune mechanisms responsible for spontaneous abortion. Med Hypotheses 57: 337-343, 2001. PMID: 11516226. DOI: 10.1054/mehy.2001.1333

45 Check JH, Dix E and Sansoucie L: Support for the hypothesis that successful immunotherapy of various cancers can be achieved by inhibiting a progesterone associated immunomodulatory protein. Med Hypotheses 72: 87-90, 2009. PMID: 18842348. DOI: $10.1016 /$ j.mehy.2008.05.042

46 Check JH: The role of progesterone and the progesterone receptor in cancer. Exp Rev Endo Metab 12: 187-197, 2017. PMID: 30063455. DOI: 10.1080/17446651.2017.1314783

47 Check JH, Sansoucie L, Chern J, Amadi N and Katz Y: Mifepristone treatment improves length and quality of survival of mice with spontaneous leukemia. Anticancer Res 29(8): 29772980, 2009. PMID: 19661303.

48 Check JH, Dix E, Wilson C and Check D: Progesterone receptor antagonist therapy has therapeutic potential even in cancer restricted to males as evidenced from murine testicular and prostate cancer studies. Anticancer Res 30: 4921-4924, 2010. PMID: 21187471.

49 Check JH, Sansoucie L, Chern J and Dix E: Mifepristone treatment improves length and quality of survival of mice with spontaneous lung cancer. Anticancer Res 30: 119-122, 2010. PMID: 20150625.

50 Check JH, Dix E, Sansoucie L and Check D: Mifepristone may halt progression of extensively metastatic human adenocarcinoma of the colon - case report. Anticancer Res 29(5): 1611-1613, 2009. PMID: 19443374.

51 Check JH, Wilson C, Cohen R and Sarumi M: Evidence that mifepristone, a progesterone receptor antagonist, can cross the blood brain barrier and provide palliative benefits for glioblastoma multiforme grade IV. Anticancer Res 34: 23852388, 2014. PMID: 24778047.

52 Check JH, Dix E, Cohen R, Check D and Wilson C: Efficacy of the progesterone receptor antagonist mifepristone for palliative therapy of patients with a variety of advanced cancer types. Anticancer Res 30: 623-628, 2010. PMID: 20332480. 
53 Check JH, Check D, Wilson C and Lofberg P: Long-term highquality survival with single-agent mifepristone treatment despite advanced cancer. Anticancer Res 36: 6511-6513, 2016. PMID: 27919975.

54 Check JH, Check D and Poretta: Mifepristone extends both length and quality of life in a patient with advanced non-small cell lung cancer that has progressed despite chemotherapy and a check-point inhibitor. Anticancer Res 39: 1923-1926, 2019. PMID: 30952734.

55 Ji Y, Rankin C, Grunberg S, Sherrod AE, Ahmadi J, Townsend JJ, Feun LG, Fredericks RJ, Russell CA, Kabbinavar FF, Stelzer KJ, Schott A and Verschraegen C: Double-blind phase III randomized trial of the antiprogestin agent mifepristone in the treatment of unresectable meningioma: SWOG S9005. J Clin Oncol 33(34): 4093-4098, 2015. PMID: 26527781. DOI: 10.1200/JCO.2015.61.6490

56 Daniel AR, Hagan CR and Lange CA. Progesterone receptor action: defining a role in breast cancer. Expert Rev Endocrinol Metab 6(3): 359-369, 2011. PMID: 21857868. DOI: 10.1586/ eem. 11.25

57 Acevedo HF, Tong JY and Hartsock RJ: Human chorionic gonadotropin - beta subunit gene expression in cultured human fetal and cancer cells of different types and origins. Cancer 76 : 1467-1475, 1995. PMID: 8620425.

58 Check JH, Sarumi M, Diantonio A, Hunter K, Simpkins G and Duroseau M: Serum levels of the progesterone induced blocking factor do not precipitously rise in women with gynecologic cancer in contrast to women exposed to progesterone. Clin Exp Obstet Gynecol 42: 563-567, 2015. PMID: 26524797.

59 Check JH, Rosenberg A, Check DL, DiAntonio A, Rui H, Cohen $\mathrm{R}$ and DiAntonio G: Serum levels of the immunomodulatory protein, progesterone induced blocking factor (PIBF) which is found in high levels during pregnancy is not higher in women with progesterone $(\mathrm{P})$ receptor $(\mathrm{R})$ positive $v s$. negative breast cancer. Clin Exp Obst Gynecol 44: 187-189, 2017. PMID: 29746019
60 Check JH, Dougherty MP, DiAntonio G, Vaniver J, Duroseau M and Srivastava MD: Comparison of serum progesterone levels of the immunomodulatory protein, the progesterone induced blocking factor, in people with BRCA-2 mutations associated with and not associated with a high risk of cancer. In: Proceedings of the American Association for Cancer Research, April 18-22, Philadelphia, PA, USA. AACR, abstract nr. 1282, 2015.

61 Madendag Y, Sahin E, Madendag IC, Sahin ME, Acmaz G and Karaman H: High immune expression of progesterone-induced blocking factor in epithelial ovarian cancer. Technol Cancer Res Treat 17: 1533033818783911, 2018. PMID: 29962287. DOI: $10.1177 / 1533033818783911$

62 Kozma N, Halasz M, Polgar B, Poehlmann TG, Markert UR, Palkovics T, Keszei M, Par G, Kiss K, Szeberenyi J, Grama L and Szekeres-Bartho J: Progesterone-induced blocking factor activates STAT6 via binding to a novel IL-4 receptor. J Immunol 76(2): 819-826, 2006. PMID: 16393965. DOI: 10.4049/ jimmunol.176.2.819

63 Halasz M, Polgar B, Berta G, Czimbalek L and SzekeresBarthoJ: Progesterone induced blocking factor differentially regulates trophoblast and tumor invasion by altering matrix metalloproteinase activity. Cell Mol Life Sci 70: 4617-4630, 2013. PMID: 23807209. DOI: 10.1007/s00018-013-1404-3

64 Wan L, Dong H, Xu H Ma J, Zhu Y, Lu Y, Wang J, Zhang T, Li T, Xie J, Xu B, Xie F, Gao Y, Shao J, Tu X and Jia L: Aspirin, lysine, mifepristone and doxycycline combined can effectively and safely prevent and treat cancer metastasis: prevent seeds from gemmating on soil. Oncotarget 6: 35157-35172, 2015. PMID: 26459390. DOI: 10.18632/oncotarget.6038

Received April 10, 2019

Revised June 11, 2019

Accepted June 18, 2019 